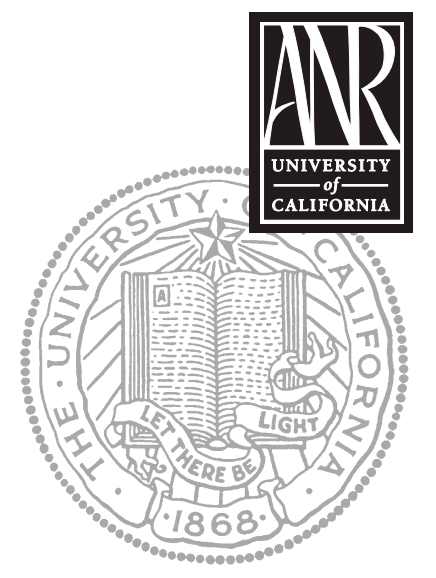

UNIVERSITY OF CALIFORNIA

Division of Agriculture and Natural Resources

http://anrcatalog.ucdavis.edu
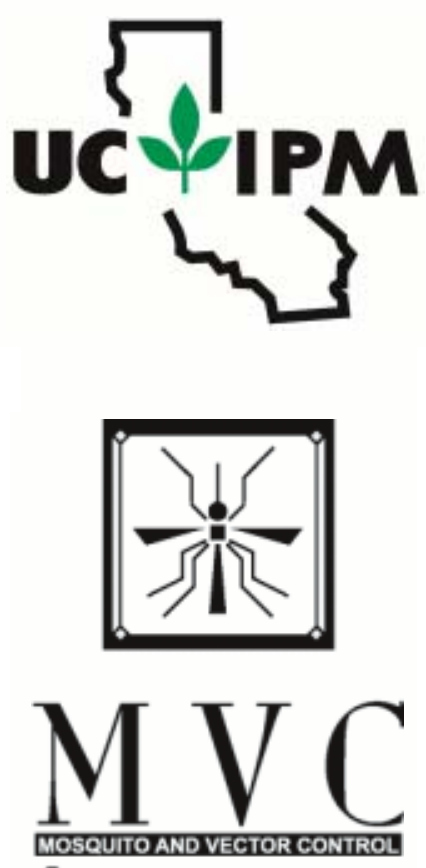

A S S OCIATION of CALIFORNIA

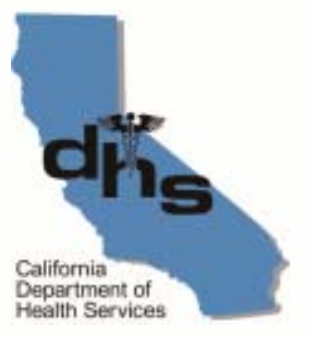

$\bigcup_{P \in R}$

REVIEWED

\title{
Managing Mosquitoes in Stormwater Treatment Devices
}

MARCO E. METZGER, Vector-Borne Disease Section, California Department of Health Services

The federal Clean Water Act, as amended in 1987, requires states to develop and implement nonpoint source pollution management programs (see Copeland 1999, 2003). These mandated programs require that certain measures be taken to abate pollutants carried by rainwater and urban (i.e., dry weather) runoff, herein collectively referred to as stormwater runoff. A principal component of stormwater programs is the implementation of Best Management Practices (BMPs), a term first adopted in the 1970s to represent actions and practices used to reduce the flow rates and the constituent concentrations in runoff (WEF and ASCE 1998).

The regulatory pressure to achieve increasingly higher levels of pollution abatement gave birth to a burgeoning industry that specializes in developing stormwater treatment devices based on the latest available technologies. These "treatment" BMPs are engineered to maximize the capture and removal of target pollutants from stormwater, often with the added benefit of reducing excessive downstream flows. Hundreds of designs have been developed across the United States, including many proprietary devices, and in some cases existing structures such as flood-control basins and constructed wetlands may be modified to function as treatment BMPs to satisfy local needs. Unfortunately, although "best" for managing runoff, these devices often provide aquatic habitats suitable for mosquitoes and other vector species as an unintended consequence of their implementation (see CH2M Hill 1999; Chanda and Shisler 1980; Dorothy and Staker 1990; Florida Coordinating Council on Mosquito Control 1998; Kluh et al. 2002; McLean 2000; Metzger et al. 2002, 2003; O'Carroll 1978; Santana et al. 1994; Schimmenti 1979; Schmidt 1980; Smith and Shisler 1981). In this publication, "treatment BMP" and "treatment device" are used interchangeably.

Public health and safety is a major component of all stormwater management programs. Flood control and the reduction of waterborne pathogens are high priorities, yet mosquito management is often overlooked. Mosquito management is essential to prevent disease transmission and maintain quality of life and must be integrated into every stormwater program. This publication provides basic guidelines for mosquito management that are relevant to the location, design, and operation of proprietary and nonproprietary stormwater treatment devices. Unfortunately, the rapid growth and evolution of stormwater programs and BMP designs combined with the tremendous number of local factors that may influence mosquito production at any given site preclude any "cure-all" recommendations or solutions. Careful implementation of these guidelines will help suppress mosquito breeding while reducing health risks and discomfort, lowering costs associated with mosquito abatement, and lessening legal liability.

\section{MOSQUITOES AND MOSQUITO CONTROL}

Mosquitoes are regarded as undesirable in both rural and urban areas throughout most of the United States. Not only is their biting activity a nuisance, mosquitoes also vector (transmit) pathogens that cause human and animal diseases. The recent threat of West Nile virus compounds concerns and reinforces the need for effective mosquito control. 
There are approximately 3,000 species of mosquitoes worldwide (about 200 in the United States) and all require water to complete their life cycle (fig. 1). Mosquito control is most effective when directed at immature stages in standing water rather than at adults and is best conducted using a combination of techniques including biological, physical, chemical, and in states such as California, legal control (California Health \& Safety Code [H\&S Code], §\$2060-2067, 100170, 100175). Biological control uses or enhances natural enemies of mosquitoes such as fish; physical control makes habitats less suitable for mosquito production; chemical control uses insecticides that target immatures or adults; and legal control can force uncooperative parties to eliminate breeding habitats on their property or face financial penalties.

Despite advances in mosquito management, the importance and need for careful preventative design and maintenance plans is paramount. This becomes apparent especially when faced with the limitations imposed by certain treatment BMPs as a result of their design, location, or accessibility. For example, underground treatment devices that hold permanent sources of water and produce mosquitoes are unlikely to support commonly used biological control agents, and physical controls such as exclusion

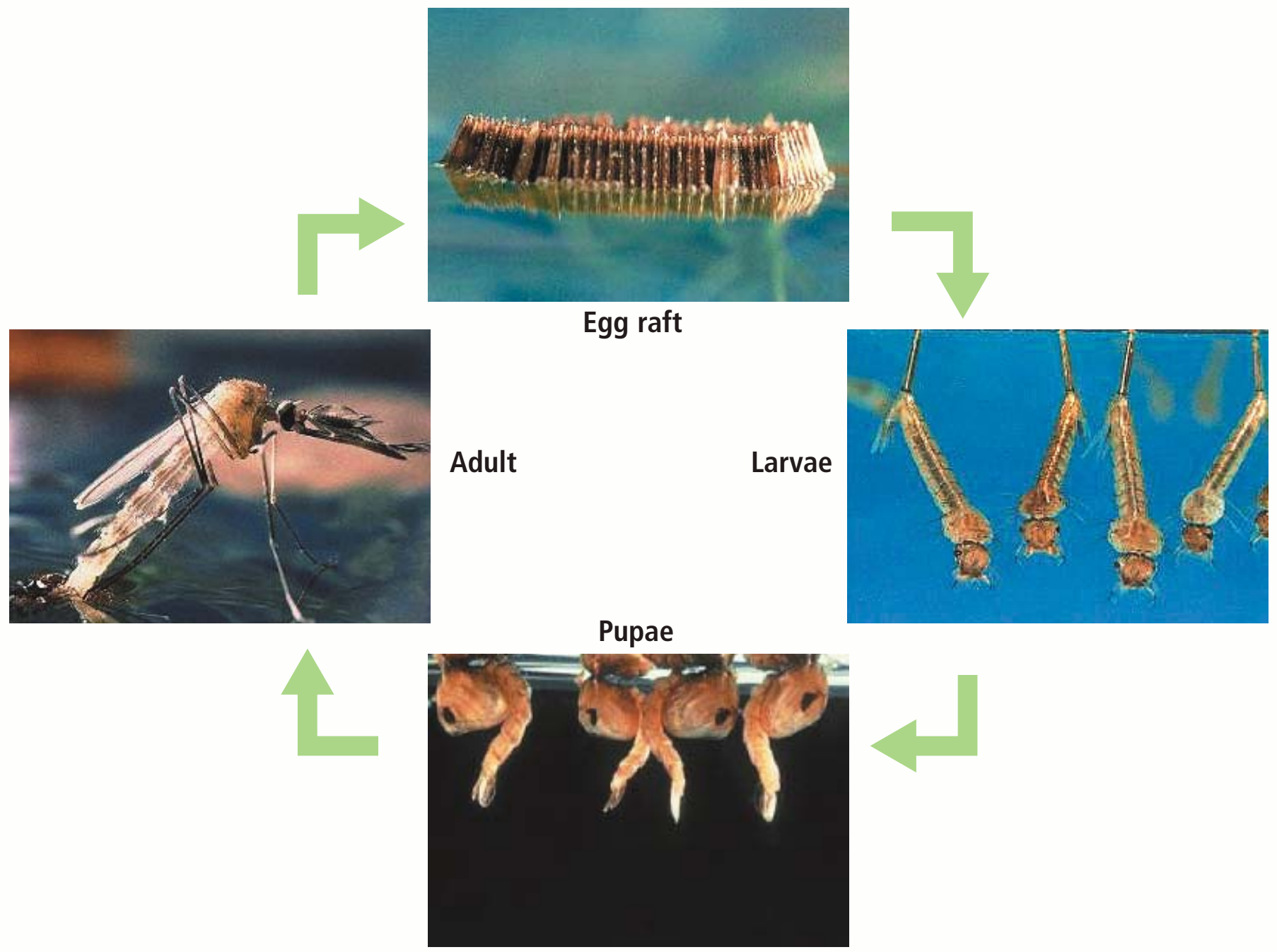

Figure 1. The mosquito life cycle consists of four stages: egg, larva, pupa, and adult. Female mosquitoes lay eggs on or near water. Eggs hatch into aquatic larvae that feed on organic material and grow through four stages before becoming pupae. Winged adults emerge from pupae, mate, and begin the cycle again. Only female mosquitoes feed on blood, which provides the nutrients needed for the development of eggs. Males are more short-lived and feed on plant juices. Photos courtesy of Marin/Sonoma Mosquito and Vector Control District. 
(e.g., valves and covers) can be difficult to implement without affecting the devices' intended function. In these situations, chemical treatment, and legal abatement in some states, are the only remaining options. Note that in this publication, "chemical treatment" refers to the use of registered pesticides to control the aquatic stages of mosquitoes (larvicides), including bacteria, hormone mimics, and oils.

\section{LARVICIDING VERSUS PREVENTATIVE ENGINEERING}

As more and more stormwater programs recognize the importance of integrating mosquito control into their lists of public health priorities, the dilemma of how to effectively manage mosquitoes in designs that favor mosquito breeding becomes obvious. Larvicide treatments are increasingly considered as long-term solutions for mosquito control in lieu of costly retrofits, replacements, or redesigns. However, sole reliance on larvicides is not a long-term solution for preventing mosquito production. Every possible effort should be made to "design the bugs out" during preconstruction planning or via postconstruction retrofits to avoid creating a possible public health hazard. When all else fails, registered pesticides should be applied only by certified professionals due to the risk of establishing pesticide resistance in target organisms, as well as potential liability issues from misuse.

\section{TYPE AND LOCATION OF TREATMENT BMPS}

When selecting and installing stormwater treatment devices, agencies consider factors such as the projected runoff for a given area, the available or allocated space, cost, and local pollutants of concern. Structural designs can range from simple to elaborate and appear to be limited only by funding and the imagination of engineers. The most common processes used for pollution management in treatment BMPs that may be used singly or in combination include trash capture, settling and sedimentation, media filtration, and infiltration. Typical urban and suburban treatment devices include vegetated channels (swales), dry detention basins, wet retention ponds or constructed wetlands, media filtration devices, and belowground sumps, vaults, and basins. Of con-

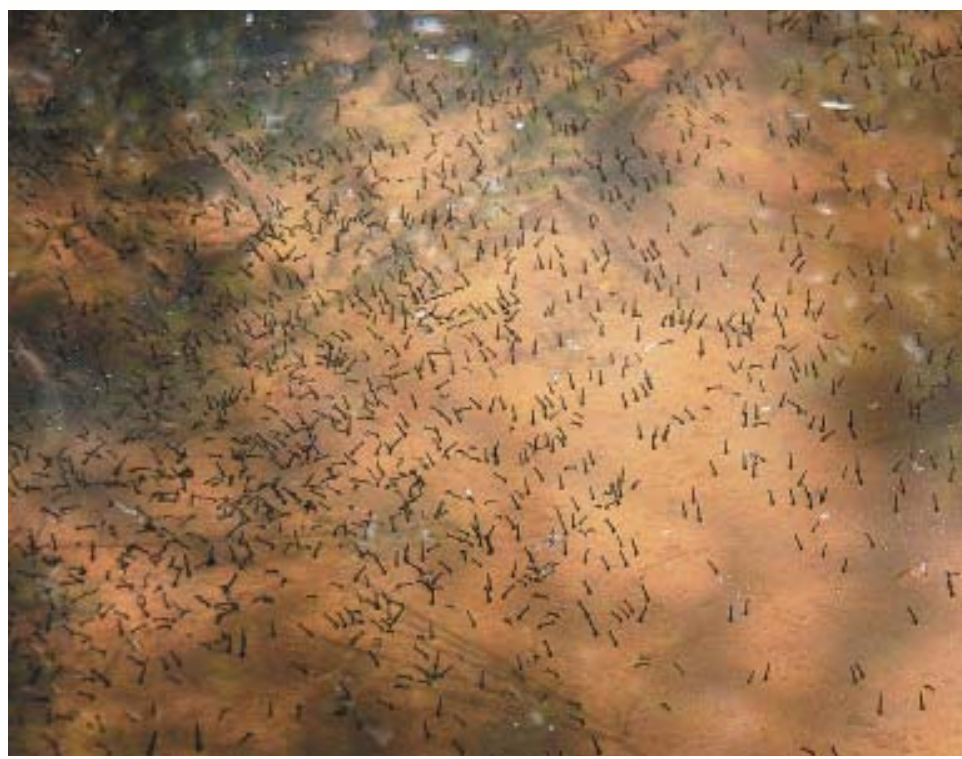

Figure 2. Waters rich in accumulations of organic materials created by some treatment BMPs provide ideal larval habitats for many species of mosquitoes, including those that can transmit human diseases. The standing water in this small roadside stormwater basin harbored hundreds of mosquito larvae and illustrates the reproductive potential of mosquitoes when provided with suitable habitat. Photo: Marco Metzger. cern to public health officials is that an alarming number of these devices hold nutrient-rich stagnant water that provides breeding places for mosquitoes (fig. 2).

Location can greatly affect whether a treatment BMP becomes a significant source of mosquitoes. For example, identical structures in different locations may vary widely in potential mosquito production due to the number of mosquitoes present in the area, the species composition, and the duration of breeding activity. Elements that may influence the mosquito breeding potential in any given location may include a variety of environmental, construction, and local factors operating singly or in combination (table 1). Because of their propensity to breed mosquitoes, all treatment BMPs, regardless of their design, should be monitored periodically by vector control professionals with knowledge of the biology and ecology of local mosquito species. A more proactive approach would be to include vector 
Table 1. Factors that may influence mosquito production potential in treatment BMPs.

Elevation

Installation above or below ground

Local climate

Local fauna (i.e., potential predators)

Nonstormwater runoff quantity, quality, and event frequency (e.g., residential and commercial)

Proximity to existing mosquito sources

Stormwater runoff quantity, quality, and event frequency

Surrounding host animals (wild and domestic) potentially available for female mosquitoes to feed upon

Surrounding land use, both present and future

Surrounding structural refuges for adult mosquitoes (e.g., trees, shrubs, storm sewers)

Surrounding vegetation, both native and exotic

Note: This list is incomplete. Other local factors may also be conducive to mosquito production. control professionals in preconstruction planning. This type of collaborative effort could help prevent costly future retrofits or replacements necessary to meet mosquito management goals.

\section{MOSQUITO SUPPRESSION THROUGH DESIGN AND MAINTENANCE}

The majority of treatment BMPs operate as "passive" systems, meaning that they do not require active operational control or adjustment beyond routine maintenance. As a result, most installations remain unsupervised for extended periods, and if conditions are favorable, mosquito breeding could occur unobserved and uncontrolled. Conscientious planning that emphasizes mosquito habitat reduction or elimination in both design and maintenance plans can prevent these problems (Metzger et al. 2002; O'Carroll 1978; Schimmenti 1979). Minimizing the mosquito production potential of treatment BMPs requires that standing water not be available for sufficient time to permit emergence of adult mosquitoes. This can be achieved in one of three ways:

- Rapid discharge of all captured water.

- Denying mosquitoes access to standing water (e.g., tight-fitting covers).

- Making the habitat less suitable for breeding (e.g., vegetation management, mosquitofish).

Mosquito development from egg to adult varies by species and is influenced primarily by temperature and food availability. Certain species can complete the aquatic stages of development and emerge as adults in less than 1 week under ideal conditions. Because of this, a 72-hour maximum residence time for captured water in treatment BMPs is recommended in California and elsewhere as a conservative safeguard to prevent emergence of adult mosquitoes (Florida Coordinating Council on Mosquito Control 1998; Metzger et al. 2003; Santana et al. 1994). In reality, many treatment BMPs hold water for over 72 hours, sometimes due to their outdated designs, and more recently in order to meet stringent effluent water quality requirements. To ensure that public health and safety is maintained, the following suggestions should be considered for any structure that holds water for over 72 hours.

- Select or design an alternative (or modified) device that provides adequate constituent removal and complete drainage in 72 hours. This is the most reliable and cost-effective choice.

- Contact state or local public health or vector control agencies to determine whether local mosquito species and local factors (e.g., high elevation) may preclude rapid mosquito emergence, thus safely allowing water residence times to exceed 72 hours. In some areas this may require a detailed study that should be funded by the soliciting party.

- Provide adequate funds necessary to support routine mosquito monitoring and control.

Possibly the most overlooked aspect of treatment BMP implementation is the long-term commitment of funds necessary for proper maintenance of structures. Routine and timely maintenance is critical for suppressing mosquito breeding as well as for meeting local water quality goals. If maintenance is neglected or inappropriate for a given site, even structures designed to be the least "mosquito friendly" may 
become significant breeding sites. Table 2 lists conditions that may increase the probability of breeding mosquitoes over time in various treatment BMPs. Maintenance guidelines for individual BMPs are often site-specific and are beyond the scope of this publication.

Table 2. Postconstruction conditions that may increase the probability of mosquito production in treatment BMPs.

Clogging (e.g., effluent pipes, media filters, infiltration basins)

Establishment of invasive or exotic vegetation Groundwater fluctuations

Nonstormwater runoff (i.e., increases in runoff frequency, residence time, and/or volume)

Scouring and erosion

Structural damage (e.g., shifting or settling, roots)

Trash and sediment accumulation (e.g., formation of pools, clogging, redirected water flows)

Vandalism

Vegetation overgrowth

Note: This list may be incomplete. Other conditions favorable to mosquito production may become apparent as structures age.

\section{BASIC GUIDELINES FOR MOSQUITO MANAGEMENT}

\section{Dry Systems}

This category includes all stormwater treatment devices that are designed to drain completely following a storm event and remain dry. Examples include extended detention (dry detention) basins, vegetated swales, infiltration devices, and media filters.

- Design structures so they do not hold standing water for more than 72 hours. Special attention to groundwater depth is essential.

- Incorporate features that prevent or reduce the possibility of clogged discharge orifices (e.g., debris screens). The use of weep holes is not recommended due to rapid clogging.

- Use the hydraulic grade line of the site to select a treatment BMP that allows water to flow by gravity through the structure. Pumps are not recommended because they are subject to failure and often require sumps that hold water.

- Design distribution piping and containment basins with adequate slopes to drain fully and prevent standing water. The design slope should take into consideration buildup of sediment between maintenance periods. Compaction during grading may also be needed to avoid slumping and settling.

- Avoid the use of loose riprap or concrete depressions that may hold standing water (fig. 3).

- Avoid barriers, diversions, or flow spreaders that may retain standing water.

\section{Systems with Sumps, Vaults, or Basins}

This category includes all stormwater treatment devices, except ponds and wetlands, that incorporate features that hold permanent or semipermanent standing water. Sumps, vaults, and basins may be located both above and below ground, but they are particularly common features of belowground proprietary and nonproprietary treatment devices that tie into existing storm sewers. Examples include above- and belowground media filters, oilwater separators, vortex separators, and vault-type devices (fig. 4).

- Completely seal structures that retain water permanently or longer than 72 hours to prevent entry of adult mosquitoes. Adult female mosquitoes may
Figure 3. The use of loose rocks (riprap) to dissipate the energy of incoming runoff encourages mosquito production. Inevitably, standing water collects between the rocks, providing habitat for mosquitoes and making monitoring and control very difficult. A lowmaintenance sloped concrete slab with imbedded rocks or concrete blocks is recommended as an alternative. Photo: Marco Metzger. 


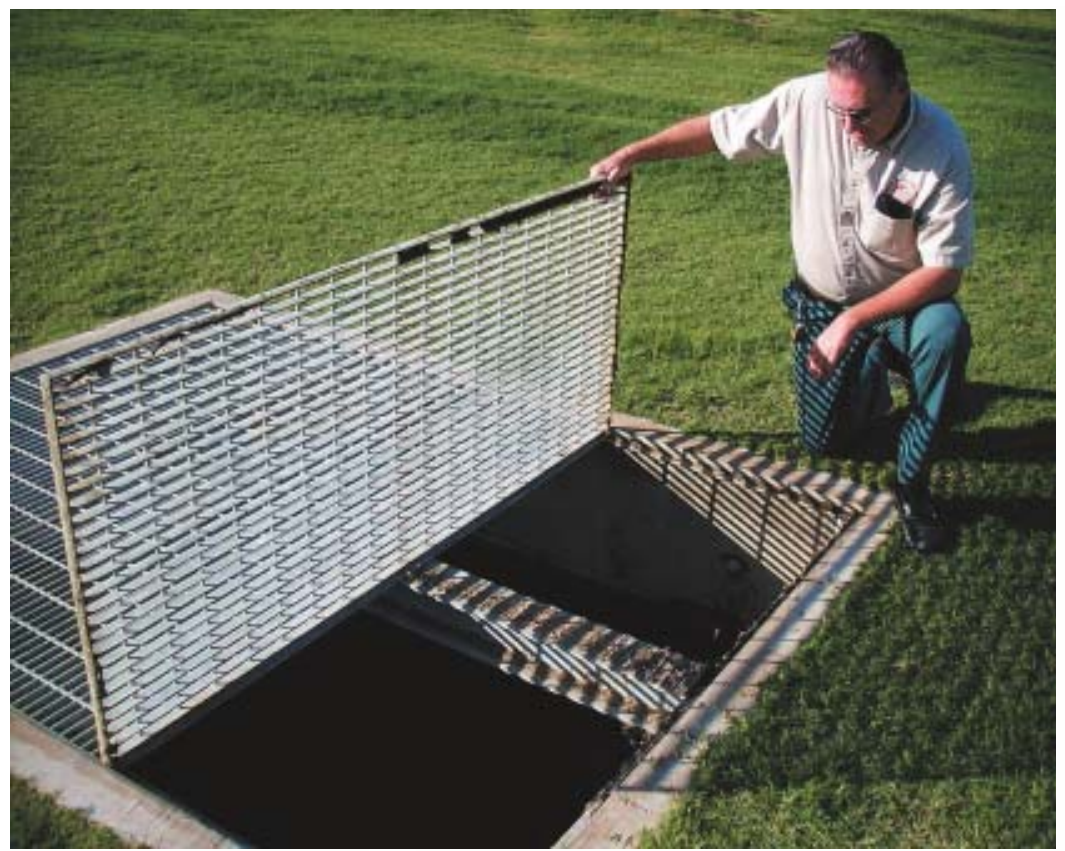

Figure 4. Stormwater treatment BMPs that hold permanent sources of standing water, especially belowground devices, pose a difficult challenge to mosquito exclusion efforts. A cooperative effort between stormwater professionals, municipal planners, public health officials, vector control agencies, and others is crucial to developing novel techniques that eliminate or deny mosquitoes access to standing water. Contact the state or local public health or vector control agency to discuss local vector issues and provide input and consultation on siting, design, and maintenance of proposed treatment BMPs. Photo: Marco Metzger.

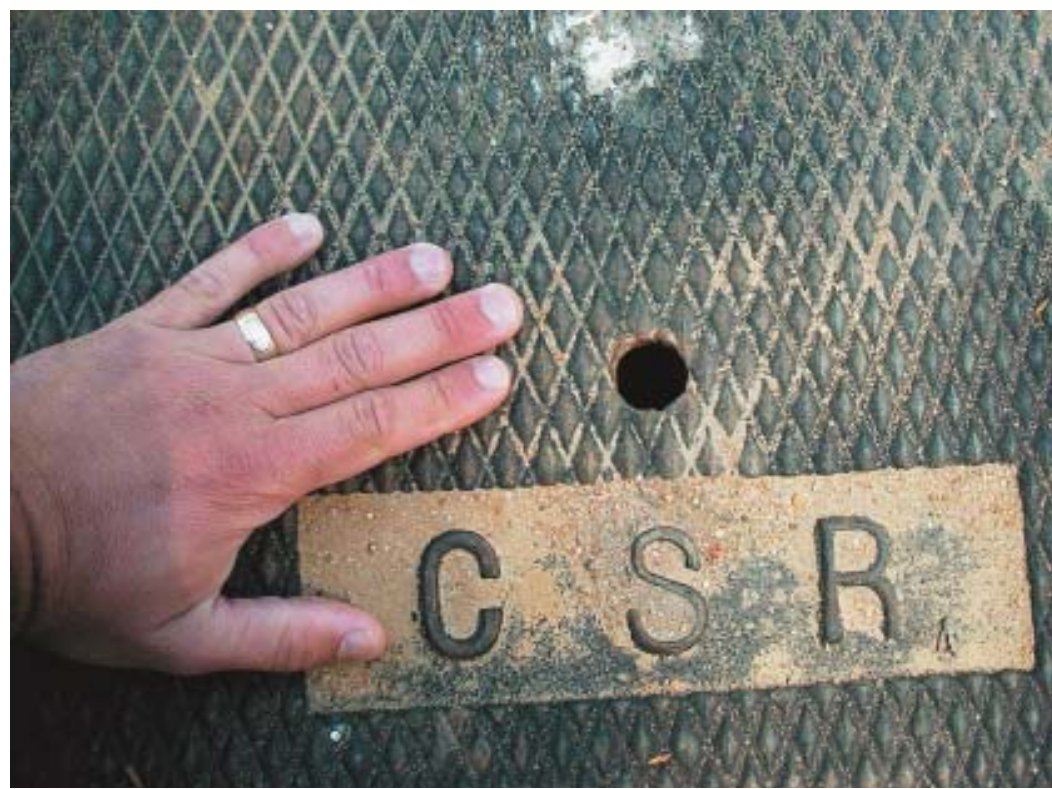

Figure 5. Mosquitoes can access underground sources of water in treatment BMPs from many places, including inlet and outlet pipes, loose-fitting covers, and vent holes. As a general rule, any gap $1 / 16$ inch $(2 \mathrm{~mm}$ ) or greater is large enough to allow egglaying females to enter. The hole in this manhole cover is more than large enough to allow mosquito entry. Photo: Marco Metzger. penetrate openings as small as $1 / 16$ inch ( $2 \mathrm{~mm}$ ) to gain access to water for egg laying (fig. 5). Screening can exclude mosquitoes, but it is subject to damage and is not a method of choice.

- If using covers, they should be tight fitting with maximum allowable gaps or holes of $1 / 16$ inch $(2 \mathrm{~mm})$ to exclude entry of adult mosquitoes. The use of gaskets can provide a much more effective barrier when used properly.

- If the sump, vault, or basin is sealed against mosquitoes, with the exception of the inlet and outlet, submerge the inlet and outlet completely to reduce the available surface area of water for mosquito egg-laying (female mosquitoes can fly through pipes).

Alternatively, creative use of flapper or pinch valves, collapsible tubes (Mulligan and Schaefer 1982), and "brush curtains" might be effective for mosquito exclusion in certain designs.

- Design structures with the appropriate pumping, piping, valves, or other necessary equipment to allow for easy dewatering of the unit if necessary.

\section{Stormwater Ponds and Wetlands}

Stormwater ponds and constructed, modified, or restored wetlands that receive runoff and provide stormwater treatment pose a difficult challenge for mosquito control because nearly all produce mosquitoes to some degree (fig. 6). Over time, emergent and shoreline vegetation create habitats conducive to mosquito breeding that may be difficult or even hazardous for mosquito control professionals to access. Hazards increase significantly if proper access (see below) is not provided. If these kinds of structures must be built, it is crucial that appropriate and adequate funds be allocated to support long-term site maintenance as well as routine monitoring and management of mosquitoes by a qualified agency. The long-term costs, jurisdictional and maintenance conflicts associated with establishment of protected species (United States Fish and Wildlife Service 1999), and legal liability (e.g., H\&S Code) associated with 


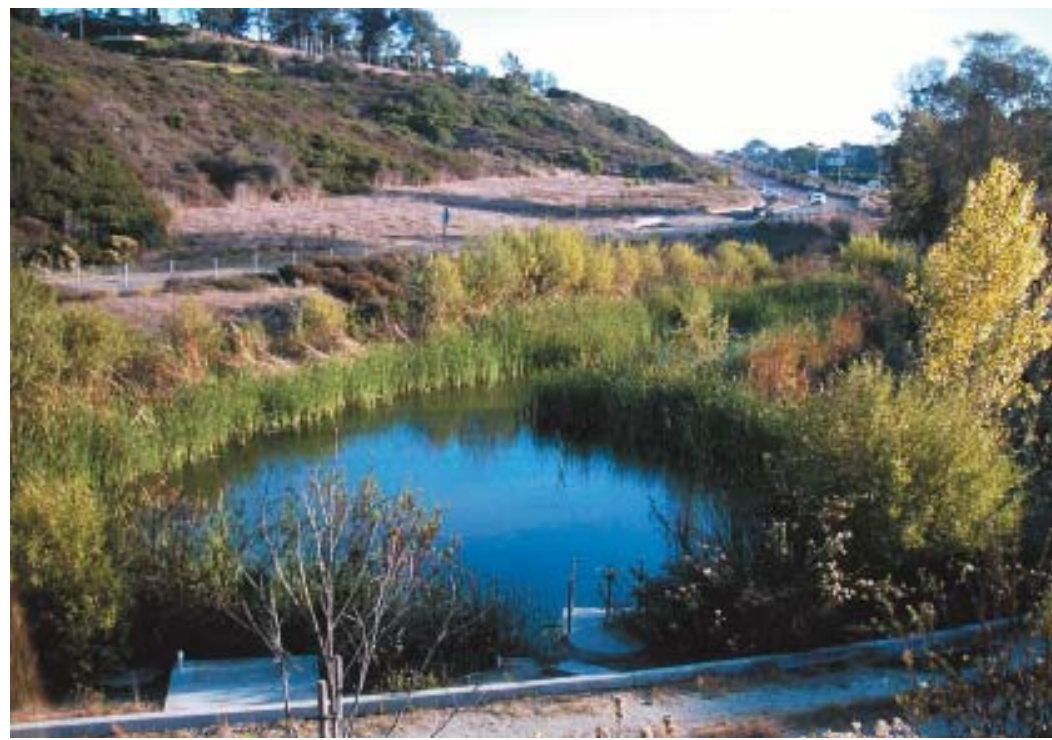

Figure 6. Stormwater treatment ponds and constructed wetlands form complex biological systems in which mosquitoes can be difficult to control. Effective mosquito management in these habitats requires careful planning before, during, and after construction. Mosquito suppression in this stormwater pond was achieved by following guidelines provided in this publication, i.e., weekly larval monitoring, annual removal of emergent vegetation, and maintenance of a healthy mosquitofish population. Additional guidelines for managing mosquitoes in surface-flow constructed wetlands are available and should be consulted (see Walton 2003). Photo: Marco Metzger. these kinds of projects must be evaluated; if any doubt exists, consider alternate treatment devices. For example, feasibility studies of subsurface flow treatment wetlands are currently under investigation and may provide excellent mosquito-free alternatives (see Anonymous 2002).

Long-term management of mosquitoes in stormwater ponds and wetlands should integrate biological control, vegetation management and other physical practices, and chemical control as appropriate. Also, a provision for regular inspection of sites for detection of developing mosquito populations should be included. Some general guidelines are listed below. Local factors may influence the overall effectiveness of certain approaches for mosquito reduction. Additional information and guidelines are available for surface-flow constructed treatment wetlands and should be consulted (Walton 2003) to ensure that mosquito populations are minimized.

\section{Mosquito Predators and Biological Control}

- Stormwater ponds and wetlands should maintain water quality sufficient to support surface-feeding fish such as mosquitofish (Gambusia affinis), which feed on immature mosquitoes and can aid significantly in mosquito control.

- If large predatory fish are present (e.g., perch and bass), mosquitofish populations may be negatively impacted or eradicated. In this case, careful vegetation management remains the only nonchemical mosquito control measure.

- Where mosquitofish are not allowed, careful vegetation management remains the only nonchemical mosquito control measure.

- Other opportunistic predators such as dragonflies, diving beetles, birds, and bats feed on mosquitoes when available, but their effects are generally not sufficient to preclude chemical treatment. Despite popular beliefs, control of adult mosquitoes by birds (e.g., purple martins) and bats cannot be relied on in lieu of habitat maintenance and chemical control (Kale 1968; Tuttle 2000).

\section{Vegetation}

- Emergent vegetation provides mosquito larvae with refuge from predators, protection from surface disturbances, and increased nutrient availability while interfering with monitoring and control efforts.

- Perform routine maintenance to reduce emergent plant densities to facilitate the ability of mosquito predators (i.e., fish) to move throughout vegetated areas.

- Whenever possible, maintain stormwater ponds and wetlands at depths in excess of 4 feet $(1.2 \mathrm{~m})$ to limit the spread of invasive emergent vegetation such as cattails (Typha spp.). Deep, open areas of exposed water are typically unsuitable for mosquito immatures due to surface disturbances and predation. Deep zones also provide refuge areas for fish and beneficial macroinvertebrates should the densely vegetated emergent zones be drained. 
- Build shoreline perimeters as steep and uniform as practicable to discourage dense plant growth.

- Use concrete or liners in shallow areas to discourage unwanted plant growth where vegetation is not necessary.

- Eliminate floating vegetation conducive to mosquito production (i.e., water hyacinth [Eichhornia spp.], duckweed [Lemna and Spirodela spp.], and filamentous algal mats).

\section{Miscellaneous}

- Make shorelines accessible to maintenance and vector control crews for periodic maintenance, control, and removal of emergent vegetation, as well as for routine mosquito monitoring and abatement procedures, if necessary.

- Design and obtain necessary approvals for all stormwater ponds and wetlands to allow for complete draining when needed.

\section{General Access Requirements}

Providing adequate and safe access for maintenance activities and for mosquito monitoring and management in stormwater treatment devices cannot be over emphasized (fig. 7). An alarmingly high number of treatment BMPs already exist that were constructed with little or no regard to reasonable access and safety. Examples include basins with 1:1 perimeter slopes, devices with deep sumps or vaults, and covered devices with heavy lids or grates.

- All stormwater treatment devices should be easily and safely accessible without the need for special requirements (e.g., OSHA requirements for "confined space"). This allows vector control personnel to effectively monitor and, if necessary, abate vectors.

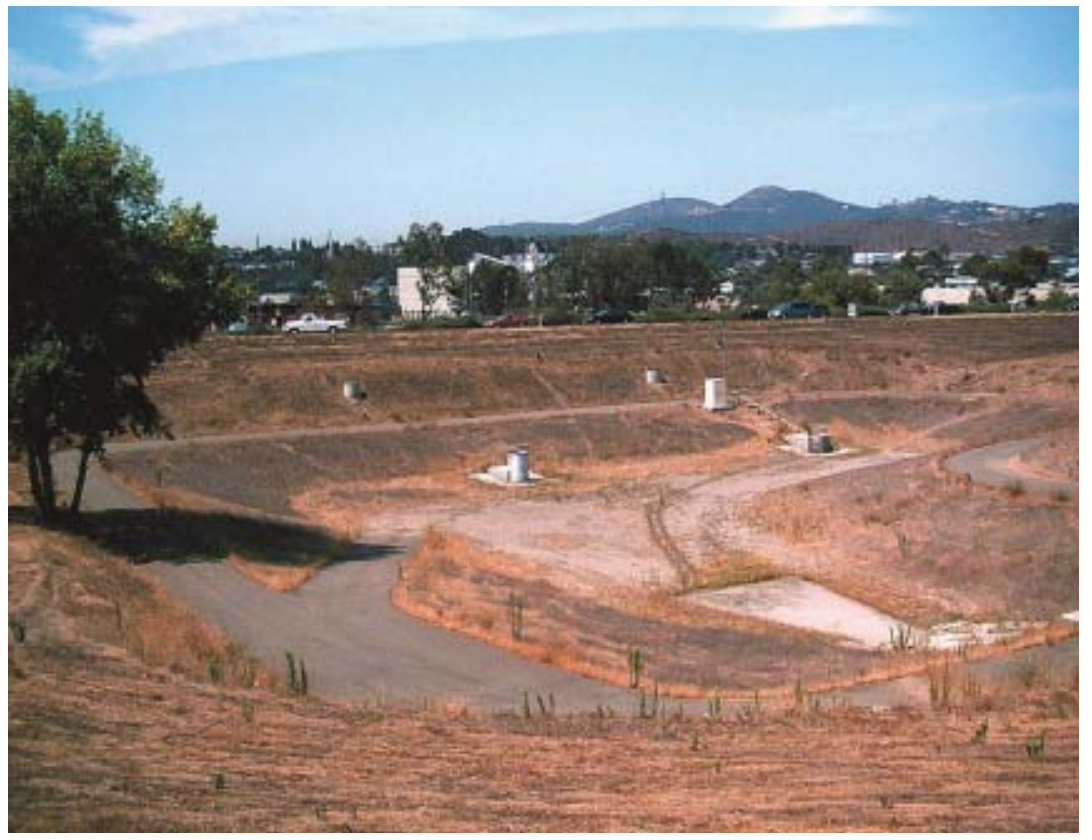

Figure 7. An example of a well-designed perimeter road and access ramp to the basin floor. Adequate access in and around BMP devices such as this large extended detention basin are critical for maintenance activities and vector control. Photo: Marco Metzger.
- If utilizing covers, the design should include spring-loaded or lightweight access hatches that can be opened easily for inspection.

- Mosquito larvicides are applied with handheld equipment at small sites and with backpack or truck-mounted high-pressure sprayers at large sites. The effective swath width of most backpack or truck-mounted larvicide sprayers is approximately 20 feet (6 m) on a windless day. Because of these equipment limitations, all-weather road access (with provisions for turning a fullsize work vehicle) should be provided along at least one side of large aboveground structures that are less than 25 feet (7.5 m) wide. Structures that have shoreline-to-shoreline distances in excess of 25 feet should have a perimeter road for access to all sides. 
- Access roads should be built as close to the shoreline as possible. Vegetation or other obstacles should not be permitted between the access road and the stormwater treatment device that might obstruct the path of larvicides to the water.

- Vegetation should be controlled (by removal, thinning, or mowing) periodically to prevent barriers to access.

\section{CONCLUSION}

Stormwater treatment devices, especially those that hold permanent sources of standing water by design, create a difficult challenge for public health officials and vector control agencies and may pose a legal liability in states such as California (H\&S Code). The best solution to managing mosquito populations in stormwater structures lies in fostering interdisciplinary cooperation among stormwater professionals, municipal planners, public health officials, vector control agencies, and others. Existing and future treatment BMPs must incorporate features and follow guidelines to minimize or eliminate mosquitoes. Contact state or local public health or vector control agencies to discuss local vector issues and provide input and consultation into siting, design, and maintenance of proposed treatment BMPs. Ultimately, a proactive rather than reactive approach saves money, time, effort, and most importantly, ensures the public's health.

\section{REFERENCES}

Anonymous. 2002. OCWD's dairy washwater treatment wetlands demonstration project. Land and Water 46(2): 40-45.

California Health \& Safety Code (H\&S Code). See the H\&S Web site at http://www.leginfo.ca.gov/calaw.html.

CH2M Hill. 1999. A mosquito control strategy for the Tres Rios demonstration constructed wetlands. Tempe, AZ: CH2M Hill.

Chanda, D. A., and J. K. Shisler. 1980. Mosquito control problems associated with stormwater control facilities. Proceedings of the New Jersey Mosquito Control Association 67:193-200.

Copeland, C. 1999. Clean Water Act: a summary of the law. Congressional Research Service Report RL30030. Washington, DC: National Council for Science and the Environment. See the NCSE Web site at http://www.ncseonline.org.

Copeland, C. 2003. Water quality: implementing the Clean Water Act. Congressional Research Service Report IB89102. Washington, DC: National Council for Science and the Environment. See the NCSE Web site at www.ncseonline.org.

Dorothy, J. M., and K. Staker. 1990. A preliminary survey for mosquito breeding in stormwater retention ponds in three Maryland counties. College Park: Maryland Department of Agriculture, Mosquito Control.

Florida Coordinating Council on Mosquito Control. 1998. Florida mosquito control: The state of the mission as defined by mosquito controllers, regulators, and environmental managers. Gainesville: University of Florida.

Kale, H. W., II. 1968. The relationship of purple martins to mosquito control. Auk 85(4): 654-661.

Kluh, S., M. E. Metzger, D. F. Messer, J. E. Hazelrigg, and M. B. Madon. 2002. Stormwater, BMPs, and vectors: The inevitable impact of new BMP construction on local public health agencies. Stormwater 3(2): 40-46. 
McLean, J. 2000. Mosquitoes in constructed wetlands: A management bugaboo? In T. R. Schueler and H. K. Holland, eds., The practice of watershed protection. Ellicott City, MD: Center for Watershed Protection. 29-33.

Metzger, M. E., D. F. Messer, C. L. Beitia, C. M. Myers, and V. L. Kramer. 2002. The dark side of stormwater runoff management: Disease vectors associated with structural BMPs. Stormwater 3(2): 24-39.

Metzger, M. E., C. M. Myers, and V. L. Kramer. 2003. The "dark side" of stormwater runoff management: vectors associated with BMPs. Proceedings of the California Mosquito Vector Control Association 70:2-10.

Mulligan, F. S., III, and C. H. Schaefer. 1982. A physical barrier for controlling mosquitoes which breed in urban storm drains. Mosquito News 42(3): 360-365.

O'Carroll, G. 1978. The mosquito abatement hazards of detention-retention facilities in New Jersey. Proceedings of the New Jersey Mosquito Control Association 65:158-165.

Santana, F. J., J. R. Wood, R. E. Parsons, and S. K. Chamberlain. 1994. Control of mosquito breeding in permitted stormwater systems. Brooksville: Sarasota County Mosquito Control and Southwest Florida Water Management District.

Schimmenti, F. G. 1979. Mosquito control problems associated with and general guidelines for detention and retention basins. Proceedings of the New Jersey Mosquito Control Association 66:139-148.

Schmidt, R. F. 1980. A two year study of multi-purpose water structures in Middlesex County, N.J. Proceedings of the New Jersey Mosquito Control Association 67:184-192.

Smith, C. M., and J. K. Shisler. 1981. An assessment of storm water drainage facilities as sources of mosquito breeding. Mosquito News 41(2): 226-230.

Tuttle, M. D. 2000. Bats, man-made roosts, and mosquito control. The Bat House Researcher 18(2): 6.

United States Fish and Wildlife Service. 1999. Announcement of final safe harbor policy. Federal Register 64(116): 32717-32726. See the Federal Register Web site at http://ndangered.fws.gov/policy/safe_har.pdf.

Walton, W. E. 2003. Managing mosquitoes in surface-flow constructed treatment wetlands. University of California Division of Agriculture and Natural Resources, Publication 8117. Available for free download from the UC ANR Communication Services Web site at http://anrcatalog.ucdavis.edu.

Water Environment Federation (WEF) and the American Society of Civil Engineers (ASCE). 1998. Urban runoff quality management. WEF manual of practice no. 23. ASCE manual and report on engineering practice no. 87. Alexandria, VA: Water Environment Federation; Reston, VA: American Society of Civil Engineers. 


\section{FOR MORE INFORMATION}

You'll find more information on mosquito control in the following ANR Communication Services publications

Aquatic Pest Control, Publication 3337, 2001.

Managing Mosquitoes in Surface-Flow Constructed Treatment Wetlands, Publication 8117,2003 , available for free downloading at http://anrcatalog.ucdavis.edu/pdf/8117.pdf

Mosquitoes: Pest Notes for Home and Landscape, Publication 7451, 1998.

Mosquitoes of California, 3rd edition, Publication 4084, 1978.

To order these publications, visit our online catalog at http://anrcatalog.ucdavis.edu. You can also place orders by mail, phone, or FAX, or request a printed catalog of publications, slide sets, videos, and CD-ROMs from

University of California

Agriculture and Natural Resources

Communication Services

6701 San Pablo Avenue, 2nd Floor

Oakland, California 94608-1239

Telephone: (800) 994-8849 or (510) 642-2431, FAX: (510) 643-5470

E-mail inquiries: danrcs@ucdavis.edu

An electronic version of this publication is available on the ANR Communication Services Web site at http://anrcatalog.ucdavis.edu.

\section{Publication 8125}

(C) 2004 by the Regents of the University of California, Division of Agriculture and Natural Resources. All rights reserved.

The University of California prohibits discrimination against or harassment of any person employed by or seeking employment with the University on the basis of race, color, national origin, religion, sex, physical or mental disability, medical condition (cancer-related or genetic characteristics), ancestry, marital status, age, sexual orientation, citizenship, or status as a covered veteran (special disabled veteran, Vietnam-era veteran or any other veteran who served on active duty during a war or in a campaign or expedition for which a campaign badge has been authorized).

University Policy is intended to be consistent with the provisions of applicable State and Federal laws.

Inquiries regarding the University's nondiscrimination policies may be directed to the Affirmative Action/Staff Personnel Services Director, University of California, Agriculture and Natural Resources, 300 Lakeside Drive, 6th Floor, Oakland, CA 94612-3550 (510) 987-0096. For information about obtaining this publication, call (800) 994-8849. For information on downloading, call (530) 754-5112.

$$
\text { pr-1/04-SB/CR }
$$

ISBN 978-1-60107-304-4

This publication has been anonymously peer reviewed for technical accuracy by University of California scientists and other qualified professionals. This review process was managed by the ANR Associate Editor for Pest Management. 